\title{
JEDNOGODIŠNJI PROJEKT UČITELJSKE ŠKOLE U SENJU
}

\author{
Mirko Raguž \\ Ivana Lenkovića 24 \\ HR 53270 Senj \\ mirko.raguz2@inet.hr
}

UDK: 371(497.5Senj)(091)

Stručni članak

Ur.: 2020-6-9

Pojedini poznavatelji prošlosti grada Senja znali su spomenuti da je u njihovu gradu nekada djelovala Učiteljska škola. Takve informacije uvijek su se dosad pripisivale vremenu rada i djelovanja glavnih i normalnih pučkih škola u 18. i 19. st. Međutim, tragom jednoga pisanog dokumenta u Senjskoj gimnaziji s početka pedesetih godina prošloga stoljeća, nailazi se na podatak da je u Senju školske godine 1950./1951. djelovao odjel Učiteljske škole.

Taj je pokušaj osnivanja Učiteljske škole ostao u okvirima gdje je i započeo, bez uvjeta, opremljenosti i dostatne stručnosti, ali i nedovoljne želje za nastavkom školovanja samih polaznika. Iz svega se može zaključiti kako to nije bila škola za buduće učitelje u klasičnom smislu riječi.

Ključne riječi: Učiteljska škola, dnevnik, gimnazija, nastavnici, učenici, izvješće

\section{Uvod}

Nakon Drugoga svjetskog rata u Hrvatskoj se pojavila velika potreba za učiteljima. Otvarale su se mnoge pučke škole u gradovima i selima, sve u težnji za što većim brojem pismenih osoba diljem Hrvatske. Postojeće srednjoškolske učiteljske škole u Hrvatskoj nedovoljno su osposobljavale potreban broj učitelja. Stoga ne čudi ideja o otvaranju odjela Učiteljske škole u Senju 1950./1951. jer se upravo te godine veliki broj učenika nije upisao u gimnaziju ili neki drugi postojeći školski smjer.

U pismohrani Srednje škola Pavla Rittera Vitezovića u Senju ne nailazi se na podatak tko je dao prijedlog ili neku važeću suglasnost za otvaranje takve škole. Ravnatelj gimnazije u prvom polugodištu bio je prof. Ante Radoslović, a u drugom prof. Milivoj Bačić. Nema pisanih tragova je li takva inicijativa potekla od uprave gimnazije. Međutim, u prošlosti ove ustanove postoji nekoliko primjera kada su se u okviru gimnazije organizirale tzv. škole (tečajevi) kao što 
su realka ${ }^{1}$, nautička škola ${ }^{2}$ šegrtska škola ${ }^{3}$. Sve su to bili jednokratni pokušaji osposobljavanja polaznika za ona zanimanja ili zvanja koja su tada bila potrebna. Fragmentarni školski podaci ukazuju da su to odjeli ili grupe polaznika u okviru gimnazije namijenjeni za onodobne potrebe gospodarskoga i duhovnoga života. S postojećim nastavničkim kadrom ili dijelom vanjskih suradnika kratko su djelovale i ubrzo se gasile.

Dnevnik I. razreda za školsku godini 1950./51.

U bogatoj gimnazijskoj pismohrani nalazi se samo jedan dokument Dnevnik, koji upućuje na zaključak da je doista samo jedne školske godine radio i djelovao odjel učenika prvoga razreda pri senjskoj gimnaziji pod naslovom Učiteljska škola. Nema podataka zašto se novootvoreni odjel tako zvao. Dokument ima deset stranica formata $42 \times 30 \mathrm{~cm} \mathrm{~s}$ naslovnom stranicom na kojoj piše "Škola: Učiteljska, u Senju". Na sredini stranice piše "Dnevnik 1. razreda za školsku godinu 1950./51.", a potom slijedi datum djelovanja od 1. rujna 1950. do 15. lipnja (bez upisa godine). U vlastoručnom potpisu su razrednici odjela: Nikola Šimunić i prof. Radoslavić (nema imena), koje zamjenjuje prof. Božidar Balog, sve do 15. lipnja iste godine. $\mathrm{Na}$ naslovnoj stranici Dnevnika kao razrednici su navedeni Nikola Šimunić, Ante Radoslavić i Božidar Balog, što upućuje na zaključak da je već početkom rada postojala znatna

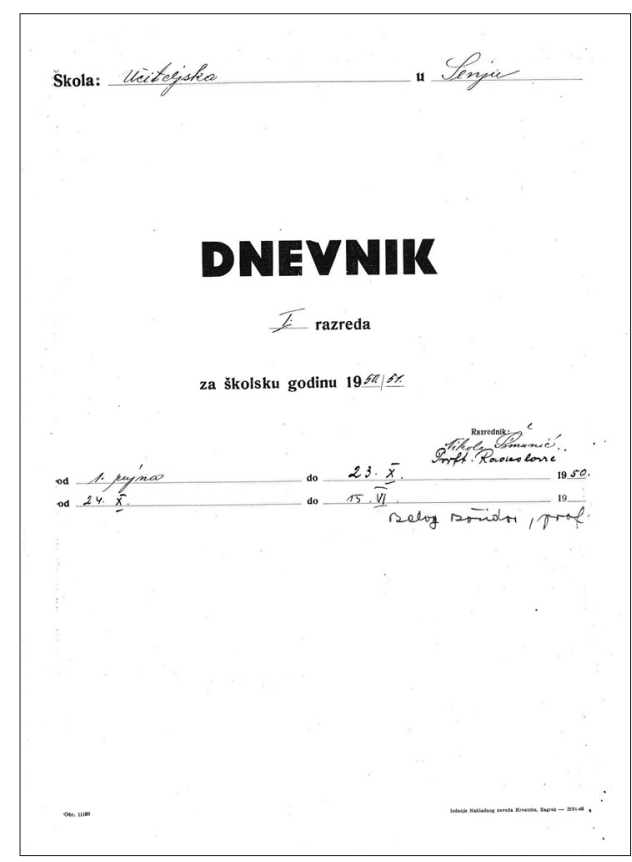

S1. 1. Preslika naslovne stranice Dnevnika I. razreda za školsku godinu 1950./1951. (izvor: pismohrana Srednje škole u Senju)

${ }^{1}$ A. CUVAJ, 1910, 118.

${ }^{2}$ Školstvo u Hrvatskoj $i$ Slavoniji od njegova početka do konca god. 1895. uz pregled humanitarnih i kulturnih zavoda: sastavljeno po službenim podacima prigodom milenijske izložbe u Budimpešti godine 1896., Kr. Hrv.-slav.-dalm. Zem. Vlada, Zagreb, 1896, 227.

${ }^{3}$ A. CUVAJ, 1911, 101-102. 


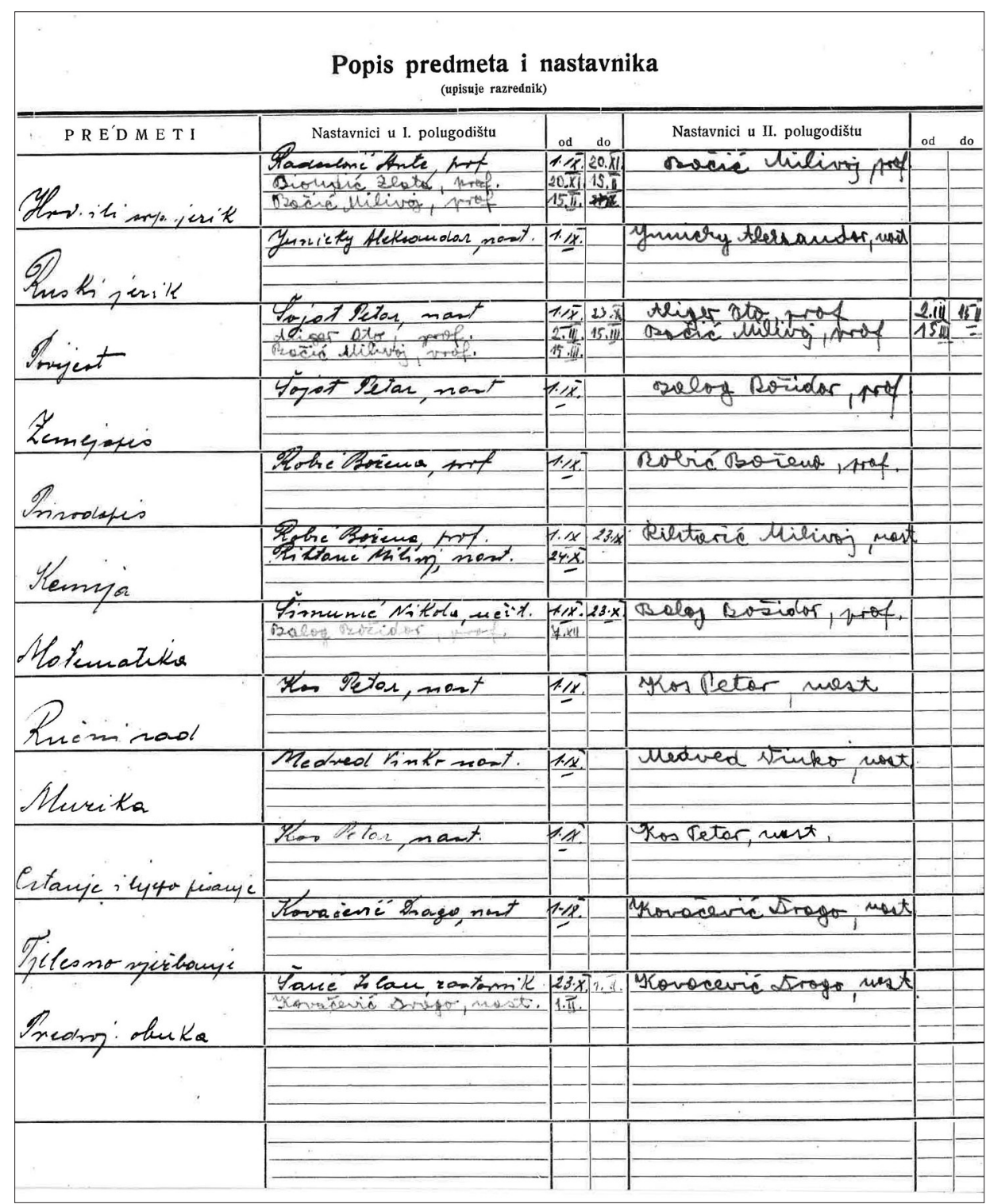

S1. 2. Popis predmeta i nastavnika Učiteljske škole

(izvor: pismohrana Srednje škole u Senju)

nedosljednost ili pomanjkanje nastavnoga osoblja za određene predmete. Sve su to bili nastavnici - djelatnici gimnazije. 
Na drugoj stranici Dnevnika nalazi se popis predmeta i nastavnika. Za Hrvatski ili srp. jezik su prof. Ante Radoslavić i Zlata Biondić u prvom polugodištu, a u drugom polugodištu do 15. lipnja prof. Milivoj Bačić; za Ruski jezik nastavnik Aleksandar Junicky; za Povijest nastavnik Petar Šojat (u prvom polugodištu) te prof. Oto Aliger i prof. Milivoj Bačić od 15. ožujka do 15. lipnja; za Zemljopis nastavnik Petar Šojat (u prvom polugodištu) te prof. Božidar Balog (u drugom polugodištu); za Prirodopis prof. Božena Robić; za Kemiju prof. Božena Robić i Milivoj Rihtarić; za Matematiku učitelj Nikola Šimunić i prof. Božidar Balog; za Ručni rad nastavnik Petar Kos; za Muziku nastavnik Vinko Medved; za Crtanje i lijepo pisanje nastavnik Petar Kos; za Tjelesno vježbanje nastavnik Drago Kovačević i za Predvojničku obuku zastavnik Islam Šarić Islam i nastavnik Drago Kovačević.

\section{Prvo polugodište u Učiteljskoj školi}

Česta izmjena nastavnika djelovala je i na kontinuitet i na ozbiljnost redovitoga pohađanja nastave. Tako je u prvom polugodištu na kvartalnoj sjednici, održanoj 10. studenoga 1950., koju je vodio ravnatelj gimnazije prof. Ante Radoslavić zapisano da je, od 52 polaznika (koliko ih je upisano na početku školske godine), devet učenika odustalo - prekinuli su školovanje. U tom prvom kvartalnom zapisniku zabilježeno je da su učenici pisali samo jednu školsku zadaću i to iz Hrvatskoga jezika, dok planirane pisane zadaće nisu pisali iz Ruskoga jezika i Matematike jer mjesec dana nisu imali nastavu iz th predmeta. Nastava se mjesec dana nije održavala ni iz Crtanja i ručnoga rada. Tih prvih mjeseci rada i djelovanja u ovome razrednom odjelu zabilježena je velika nezainteresiranost, slabo učenje i neredovito pohađanje nastave: "Razlozi za ovo mogu se naći u činjenici da se u ovu školu (učiteljsku) upisao veliki broj učenika koji nemaju volje za učiteljski poziv, već su upisani ili za to što nisu bili primljeni u koju drugu školu ili samo zato da budu učenici i to po volji svojih roditelja." Ovakvom stanju u nastavi doprinio je i nedostatak nastavnika zbog bolovanja ili nedostatka stručnog osoblja. Zbog toga je nekoliko učenika na prvoj kvartalnoj sjednici neocijenjeno, primjerice iz Ruskoga jezika 15 učenika, iz Povijesti 12 učenika, iz Zemljopisa 11 učenika, iz Matematike 14 učenika i iz Predvojničke obuke 39 učenika. Samo je 16 učenika ocijenjeno pozitivno. Takvo stanje zabilježeno je na prvom tromjesečju. Dakle, praksa je bila da se utvrđuju ocjene po nastavnim predmetima i na tromjesečjima.

Prema zapisniku s druge sjednice Nastavničkog vijeća na kraju prvoga polugodišta, 13. siječnja 1951., u razrednom odjelu bilo je 36 učenika. Sedam 


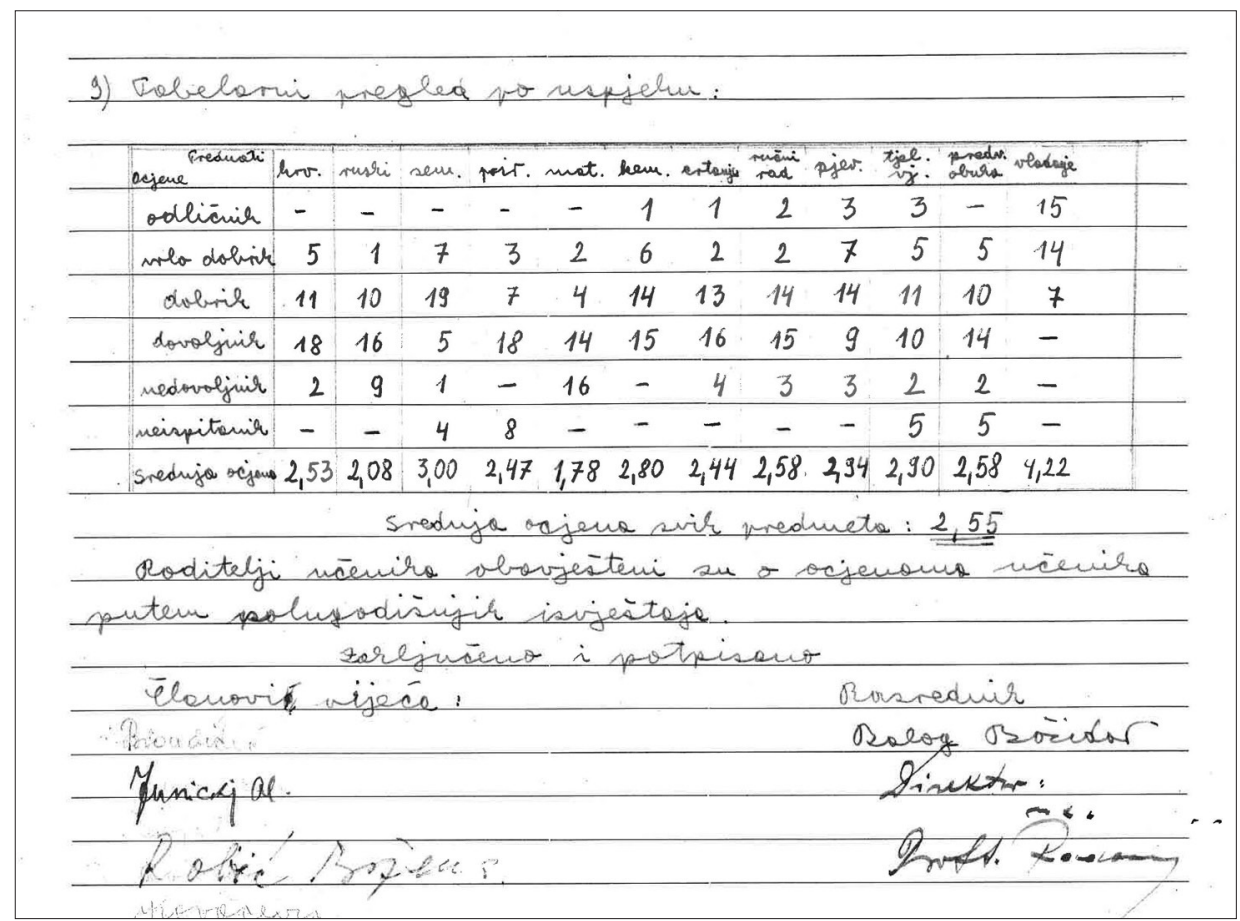

Sl. 3. Pregled uspjeha učenika na polugodištu 1950./1951.

(izvor: pismohrana Srednje škole u Senju)

učenika je odustalo od škole od 10. studenoga do 13. siječnja ili su ispisani zbog nedopuštenog vladanja. Nesređeni odnosi u nastavi tijekom prvoga polugodišta, zaključuje Nastavničko vijeće, rezultat su "odlaska nastavnika iz kemije na dopust (od 22. 11.) te bolovanja nastavnika iz prirodopisa (od 27. 11. do 8. 1.) te uslijed toga što se povijest ne predaje od 23.11." Zbog niza nedostataka i nedovoljnoga stručnog rada u nastavi na prvome polugodištu nije ocijenjeno iz Prirodopisa 8 učenika, iz Predvojničke obuke 5 učenika i iz Povijesti 36 učenika. Samo je 12 učenika ocijenjeno pozitivno. Svi ovi navedeni podaci ukazuju da su elementarni uvjeti za novoosnovani odjel učiteljskih kandidata u prvom polugodištu nedostatni i nezadovoljavajući.

\section{Drugo polugodište u Učiteljskoj školi}

U nastavku rada u drugomu polugodištu uvjeti se nisu značajnije mijenjali. O tome se nalaze podaci u zapisniku treće sjednice Razrednoga vijeća održane 9. 


\begin{tabular}{|c|c|c|c|c|c|c|c|c|c|c|c|c|c|}
\hline anjere & tent. & Aussin & 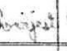 & gann & $\sin$ & wat 1 & Kaning. & Thuit & Puwi & Geacy & Evet & maing & Q sethate \\
\hline Dalicnil & 1 & $\therefore$ & 1 & 1 & - & 1 & 1 & - & 2 & - & 3 & 2 & 22 \\
\hline Falo risery & 2 & $\because$ & 4 & 16 & 8 & 4 & 6 & 5 & 1 & 7 & 9 & 6 & 9 \\
\hline Soling & 10 & 4 & 18 & 14 & 12 & 13 & 9 & 10 & 14 & 17 & 8 & 10 & 3 \\
\hline 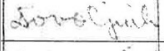 & 15 & 17 & 9 & 3 & 14 & 16 & 11 & 15 & 16 & 9 & 5 & 9 & - \\
\hline Nedienguth & - & 4 & 2 & - & - & - & 7 & 4 & - & 1 & 3 & 7 & - \\
\hline Ereanis a & 2,88 & 2,38 & $2+2$ & 3,44 & 2,82 & 2,40 & 2,50 & 2,47 & 2,74 & 4,88 & 3,14 & 2,59 & 4,56 \\
\hline
\end{tabular}

S1. 4. Uspjeh na kraju nastavne godine 1950./1951.

(izvor: pismohrana Srednje škole u Senju)

travnja 1951. koju je vodio prof. Božidar Balog. Drugo polugodište je počelo sa 35 učenika, a završeno je s 34 jer je jedna učenica zbog disciplinskih razloga prestala pohađati odjel. Problematično ponašanje učenika Nastavničko je vijeće nastojalo popraviti dodjeljivanjem ukora i opomena. Manjkavostima u nastavi doprinijeli su i nastavnici iz Zemljopisa, personalne izmjene nastavnika iz Matematike, Hrvatskoga jezika i Povijesti, a Ručni rad se nije predavao tijekom cijeloga trećeg kvartala. To je stanje rezultiralo nedostatkom ocjena iz Zemljopisa i Ručnoga rada na kraju trećeg tromjesečja. Zanimljivo je i to što su se svi prisutni nastavnici morali potpisati, na čelu s direktorom škole, na kraju zapisnika. Sva tri kvartalna zapisnika Razrednoga vijeća vrlo su uniformirana, sažeta i usmjerena na osnovne smjernice koje govore o pohađanju nastave, izostancima učenika i nastavnika te ocjenama koje su učenici postigli na kraju tih spomenutih tromjesečja.

Na kraju, na četvrtoj sjednici Razrednoga vijeća održanoj 15. lipnja 1951. tema je bila uspjeh učenika na kraju nastavne 1950./1951. godine. Zapisničar najprije bilježi da se ponašanje učenika poboljšalo u odnosu na prethodne nastavne dane te da su se izostanci s nastave smanjili. S obzirom na to da se Ručni rad kao nastavni predmet nije predavao tijekom drugoga polugodišta, Nastavničko vijeće zaključuje da se u svjedodžbu unesu ocjene iz prvoga polugodišta. Uspjeh učenika na kraju godine je nešto bolji, pa je od ukupnog broja polaznika s uspjehom završilo razred njih 22 ili 64,70 \%, dok ih je šest upućeno na ponavljanje razreda. Ni jedan učenik nije završio školsku godinu s odličnim uspjehom. U nastavku ovoga završnog zapisnika nalazi se pojedinačni popis učenika i njihov uspjeh na kraju nastavne godine. S vrlodobrim uspjehom prvi su razred završili Dušan Knežević, Vladimir Pavlović, Milan Šimičić, Ante Pičuljan i Travašić (ime nečitljvo); s dobrim uspjehom Ljubomir Andrić, Franjo Beg, Nada Frankić, Vazmoslava 


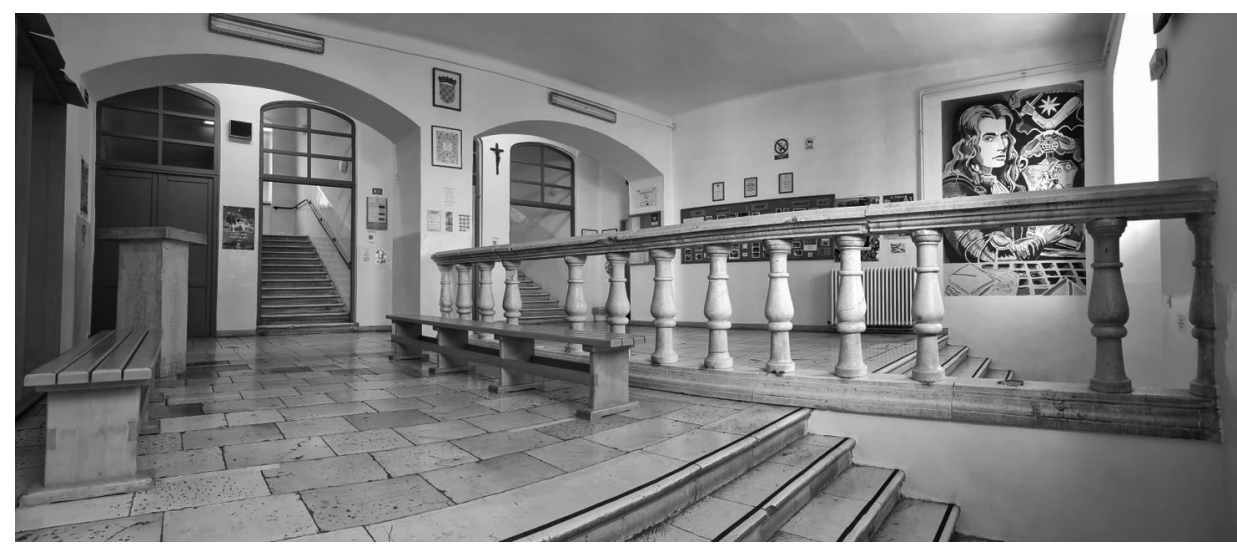

S1. 5. Aula Srednje škole u Senju - 27. rujna 2021.

(foto: Danijela Vukelić)

Hrabrić, Nada Karleuša, Marija Kralj, Josip Nekić, Isak Prpić, Jurica Sertić, Marija Travaš, Anton Vidas i Ruža Buneta; s dovoljnim uspjehom Vladimir Gržin, Juraj Krmpotić, Mirko Prpić, Martin Žumberac i Drago Biondić. Na popravni ispit upućeni su Milan Bačić (Kemija), Olga Gradišer (Predvojnička obuka), Josip Lopac (Fiskultura), Božidar Martulaš (Kemija), Albina Vukelić (Fiskultura) i Marija Matičić (Kemija). Na ponavljanje razreda upućeni su Nada Borović, Zora Lončarić, Marija Šojat, Iskra Žic i Đurđica Krmpotić.

Svjedožbe su podijeljene učenicima 16. lipnja 1951. zbog upućivanja zamolbi za nastavak školovanja u Učiteljskoj školi. Nema pisanih tragova u pismohrani Srednje škole u Senju jesu li učenici, koji su s uspjehom završili prvi razred, nastavili daljnje školovanje u drugim školskim središtima poput Rijeke, Karlovca ili Gospića. Nema pisanih tragova ni u onodobnim tiskovinama ili stručnim časopisima bliže i daljnje okoline. Taj je pokušaj osnivanja Učiteljske škole ostao u okvirima gdje je i započeo, bez uvjeta, opremljenosti i dostatne stručnosti, ali i nedovoljne želje za nastavkom školovanja samih polaznika. Iz svega se može zaključiti kako to nije bila škola za buduće učitelje u klasičnom smislu riječi.

\section{Zaključak}

Ova nesumnjivo humana namjera školovanja učenika u Senju za plemeniti učiteljski poziv ostala je ipak neostvarena zamisao. Temeljni uvjeti za školu su učenici, učitelji, nastavnici i prostor. Nažalost, tih uvjeta u Senju 
samo nekoliko godina poslije Drugoga svjetskoga rata nije bilo, posebice nastavnika. Stoga je pokušaj organizacije i rada Učiteljske škole propao. U Srednjoj školi u Senju nema nikakvih pisanih dokumenata, školskih zapisnika ni bilješki u stručnoj literaturi koje su eventualno zabilježile podatke o nastavku rada Učiteljske škole.

\section{Literatura}

I. Izvori

Dnevnik I. razreda za školsku godinu 1950./1951. (pismohrana Srednje škole u Senju)

\section{Knjige}

Antun CUVAJ, Građa za povijest školstva, sv. II., Trošak i naklada Kr. hrv.-slav.-dalm. zem. vlade, Odjela za bogošt. i nastavu, Zagreb, 1910.

Antun CUVAJ, Građa za povijest školstva, sv. VII., Trošak i naklada Kr. hrv.-slav.-dalm. zem. vlade, Odjela za bogošt. i nastavu, Zagreb, 1911.

Školstvo u Hrvatskoj i Slavoniji od njegova početka do konca god. 1895. uz pregled humanitarnih $i$ kulturnih zavoda: sastavljeno po službenim podacima prigodom milenijske izložbe u Budimpešti godine 1896., Kr. Hrv.-slav.-dalm. Zem. Vlada, Zagreb, 1896.

\section{ONE-YEAR PROJECT OF THE TEACHER TRAINING SCHOOL IN SENJ}

\section{Summary}

Some experts of the past of the town of Senj used to mention that there was once a Teacher's School in their town. Until now, such information had always been attributed to the time of the work and activity of the main and normal public schools in the $18^{\text {th }}$ and $19^{\text {th }}$ centuries. However, on the basis of one written document in the Senj grammar school from the beginning of the 1950s, it can be seen that in Senj in the school year of 1950-1951 a department of a Teacher's School was functioning.

This attempt to establish a Teacher's School remained within the framework where it began, without conditions, equipment and sufficient expertise, as well as an insufficient wish to continue the education of the students themselves. From all of this, it can be concluded that this was not a school for future teachers in the classical sense of the word.

Keywords: Teacher's School, diary, grammar school, teachers, pupils, report 